\title{
Implementation of Innovation and Performance Measurement in Hospitality Industry using Balanced Scorecard
}

\author{
A. Arun, Ali A. Alalmai
}

\begin{abstract}
The hospitality industry in India is set to grow at an average rate of fifteen percent per annum in the next five years the growth of the industry need to be supported by the implementation of innovative practices by the companies in order to compete effectively in the market and enhance sales and profits. It should be noted that better financial performance is considered as the main objective of any organisation's existence. To achieve the stated performance the management need to continuously adapt to changes and innovate. In reality, very few hospitality organisations tend to innovate in a more creative manner so as achieve the desired results. Therefore it is not only the innovation which brings success to the organisation, but also managing the performance strategically is important to be successful. In summary, this conceptual paper offers a primary and imperative attempt to understand the inhibition and performance measurement of innovation into hospitality industry.
\end{abstract}

Key Words: Hospitality; Innovation; Measurement; Performance.

\section{I.INTRODUCTION}

The term "innovation" is derived from the Latin word "innovatio" which literally means that to create something new [1]. An innovation is any idea, process or product that is accepted as new by an individual [2]. Innovation is the core of an organisation's activities creating new, marketable product or services and/or new production and delivery systems [3].

To sustain the advantage over the competitors and survive the fast change circumstances innovation is primly considered to be a important and major role player in creating and developing the value of the organization [4]. Service innovations are defined as innovations in processes and in innovation in existing service products of organisation. In innovations there also exist variations in product delivery or add-on services embellishing the service experience for the customer [5].

Innovation in an organisation is the changes it makes in what it offers and in the way in which it creates and delivers those offering to the customers, [6] as a process of bringing in new products or procedures that solves the issues an organisation has with the existing ones [7].

\section{Hospitality Industry}

The hospitality industry is compose of many features, it constitute inter depending system like the accommodation, transportation, aviation, leisure etc. A mutual relationship between these systems or the parts of the sector enhances the growth of the hospitality industry.Introduction of innovative conceptual forces into the departments of hospitality sectors improves the economical growth of the sector [8].

The key players in hospitality are the major national hotel chains, international brands, new Indian brands, new operators and other indefinite characteristics, largely independent. India's leading hotel chains such as Hotel Group Taj, Oberoi Hotels \& Resorts and ITC Welcomgroup and ITDC Governments have dominated the Indian market for decades and only a few international brands were present in India. . The major international networks of hotels, Sheraton, Hilton, Hyatt, Radisson, Marriott and Le Meridien were well established in the Indian market and expanded [9]. Since China and India are the main growth factor in the global hotel industry, there are few active companies in the world. Given India's huge potential, several international brands follow. So far, about 50 international hotel chains have entered the Indian market. The proliferation of international players and advanced services, competition in the market is steadily increasing, leading to a higher degree in the professional field. With the emergence of branded goods in the hotel market, customers are increasingly demanding and expecting the entire industry create an environment that promotes innovation [10].

\section{Characteristics of Innovation:}

Rogers, 1983 and 1995 had identified innovation as just more than a process but a product of its own. He described characteristics for innovation like any other material products and this was adapted and bettered by many experts in the time after him. The characteristics are Relative advantage, Compatible, Complex, Trialable and Observable [2] the same characteristics had been identified by Clarke (1999), Frenken (2006) and Hornor (2007) in their articles pertaining to innovation.

Revised Manuscript Received on 14 September, 2019.

A. Arun. Assistant Professor, School of Hotel and Catering Management, Vels Institute of Science Technology and Advanced Studies (VISTAS), Chennai. (Mail Id: arunarticle2016@gmail.com) Mobile: 09884761244

Ali A. Alalmai. Assistant Professor, Community College, Jazan University, Saudi Arabia (Mail id: aaalalmai@jazanu.edu.sa) 


\section{TYPES OF INNOVATION}

Innovation is as old as the launch of the first product in the world. But understanding innovation and studies on it started only in mid 1950s. Innovation can be either continuous or discontinuous concepts based on their nature. This include Technical innovation [12], incremental innovation [13], Product or process innovation [14].

Francis and Bessant, (2007) came up with four modified types of innovation which includes Product innovation, Process innovation, Position innovation, and Paradigm innovation[15], Oke, (2007) tried to come up with a model which includes all types of innovations suggested by experts prior to him in three categories Product, Service and Process innovations.

\section{DRIVERS OF INNOVATION IN SERVICE}

Service innovation or otherwise known as new service development is a completely new topic in the hospitality industry. It is similar to new product development of any products with the difference being the fact that they have different characters and different factors that drive innovation in a service organisation [16].

All the organisations are conservative and there are two different motivators for bringing in changes. Those factors are Push factors- arrival of new technology, new methods of solving current issues, etc and Pull factors- arising from the increasing demand of customers. Both these factors work simultaneously in an organisation that develops new services [1].

On the other hand, Fernandez et al, 2011 had a different view saying that innovation in service is enforced by two factors concerning the organisation, the internal factors size of the organisation, ownership of the business, and the cost of innovation and availability of qualified personnel. The external factors include availability of information, customer demands and prevailing market conditions. Both these factors have to be balanced to attain innovation in an organisation [17].

Moreover, Karniouchina, Victorino and Verma, 2006 had also accepted that the need for innovating in a hospitality organisation depends on different factors at different times that can be termed as determinants of service innovation. To be summed-up that the following steps are the determinants of innovation decisions in the hospitality organisations [18].

\section{STEP 1: Identifying the need for innovation}

The first step an organisation takes is identifying and analysing the factors that encourages innovation. These factors may be Pull or Push of both factors together that motivate the organisation to launch new service.

\section{STEP 2: Analysing the resources}

Once the need is identified, the organisation then analyses the resources available both internally and externally. Internally it analyses on the finance available, the size of the business, skills of the staff and externally it analyses the data available about the new service, acceptance of this service by the customers.

\section{The Innovation process:} Innovation was primarily studied under binary types [11]

Innovative ideas are launched into the organisation through a series of stages which have to be carefully crossed by the innovators. Tate, (2012) has come up with a detailed study of how innovation takes place in a business organisation and explains the various steps that are carried out by the business during the process of innovating.

Identifying the issues: the first step of carrying out innovation in an organisation is to identify the places where innovation can be done and the issues which need innovative ideas to be solved

Scope of innovation: the next stage is to understand the scope of bringing new innovative ideas into the business. Innovation can be of internal focus where it is analysed based on sources of fund available, management decisions like fixing target, including culture of the business, etc production process and employment policies. Outward focus will be based on all external factors like the market, partners, products, price and other criteria's. All these will provide a clear view of whether the organisation has the scope of innovating.

The innovation audit: after understanding the scope of innovation, then the organisation does an innovation audit in which they analyse the existing resources available and identifying the gaps in the organisation that needs to be filled for innovating and creating tools for measuring innovation.

Planning for innovation: In this stage the management understands how the new innovative idea fits into business strategy? How to manage ideas inside the organisation? This is when the idea of whether to do innovation by themselves or outsourcing it to an outsider is decided. In this stage, this is also known as process of Ideation.

Implementation or adaption: after all the analysis, the new innovative idea is implemented in the organisation- first on a trial basis and based on its success, implemented in the whole of organisation. As any other new idea, this idea also had problems when implemented.

Control measures: at every stage proper control measures are taken as per decided based on the audit. Proper changes are made according to the necessity before implementing and after implementation as well.

Measuring performance: this is the final stage in the organisation where the performance is measured against the target set by the management towards the implementation of the new idea. The best part of an innovation is when the results are visible [19].

\section{DETERMINANTS OF SUCCESS IN INNOVATION}

The insights into New Service Development theory had mostly been developed from the New Product development theory, with huge numbers of hotels and restaurant concepts failing every year, the rate of success in Innovation among hospitality organisations remain on the lower side. Moreover the success rate in hospitality organisation is very low as the managers tend to develop a personal idea without 
conducting proper research Hospitality innovations are not merely to achieve financial performance, but it also achieves other performance objectives of the property [20].

Arguably, Innovation or new service development in hospitality industry is considered to be of high risk nature and hence lesser innovations in this sector [21]. The factors that determine the success of new service developed in an organisation can be clustered into four categories productrelated factors, market-related factors, process-related factors and organisation related factors [22].

\section{MEASURING PERFORMANCE OF INNOVATION \& RESULTS}

Performance measurement in hospitality organisations can be defined as the process in which the quantified efficiency and effectiveness of the action taken.The measurement process involves various measures like financial and non-financial measures. In the olden days, financial measures are only considered while measuring performance whereas the non-financial measures are being considered as important in the last decade. The success of an organisation now depends on the balance between the financial and non-financial measures [23].

Performance of a hospitality organisation can be measured by the results achieved through Competitiveness the change in the percentage of market share, sales growth, occupancy levels compared to the competitors and customer satisfaction, and Financial performance - which includes total sales, net profit attained, seat and inventory turnover attained, labour cost percentage and other operating cost of the organisation [24].

The important measures for measuring performance into four different categories,

Financial measures - Sales and revenue, average sales and Revenue per service provided.

Non-financial measures - Star-rating assessment reports, numbers of new customers to the organisation, and the competitors' average sales comparison.

Stakeholder satisfaction - It includes Loyalty of customers and employees to the organisation, positive feedback from the investors, and their readiness to further invest in the organisation, feedback from the communal organisation to form alliances.

Business results - the net profit and return on the investment [23].

The ideal model with which performance can be measured in an organisation is using the Balanced Scorecard [25].This helps the managers in understanding the various perspectives of the organisation and its effect on the overall performance of the organisation. This method uses 20-25 measures to calculate the performance of an organisation. Anything more than or less than this count is considered to not recommended. This tool, when properly utilised can act as a strategic approach to the performance management of the organisation. The balance scorecard revolves around the vision and strategy of the organisation [26].

The four perspectives composed in the Balanced Scorecard approach are as follows:

The learning and growth perspective - this captures the ability of the organisation to proper alignment of business. It also includes the employee abilities, information system of organisation and its adaption to the change.. Ideal value considered for this perspective is $22 \%$. For example: the number of staff suggestion considered in the NSD and staff loyalty towards the hotel along with the training provided to them explains the learning and growth perspective [27].

The Internal process perspective - It is derived from the employee capability in the organisation. This perspective is to analyse the processes that the organisation need to excel to satisfy the stakeholders needs. As this is the perspective based on which the strategy is formulated, 34\% value is given to this perspective.For example: the percentage change in the cost of service quality in the operations, control over the maintenance of the new service developed relates to this perspective [28].

The customer perspective - it indicates the related outcome through the delivery of the new service to the customers and it is an important aspect to be considered while managing performance. Ideally $22 \%$ value is given for this perspective. For example: Increase in the market share, increase in the loyal customers and increase in the customer satisfaction after the launch of new product in an organisation [29].

The financial perspective - the ultimate goal of any business is the financial outcome from it. It remains the same while a new service is developed in an organisation. This measures the improvement in the profitability of the organisation after the launch of new service. $22 \%$ is the ideal value given to this perspective [26]. Based on the understanding on the various measures used by organisations overtime according to the experts, the following measures can be considered as ideal for measuring the performance of an innovative food and beverage outlet being launched in a hospitality organisation: 
Table 1: BALANCED SCORECARD OF A NEWLY LAUNCHED F \& B OUTLET:

\begin{tabular}{|c|c|c|c|}
\hline Performance Measures & $\begin{array}{l}\text { Performance } \\
\text { Before New } \\
\text { concept }\end{array}$ & $\begin{array}{l}\text { Budgeted } \\
\text { Performance }\end{array}$ & $\begin{array}{l}\text { Actual } \\
\text { Performance }\end{array}$ \\
\hline $\begin{array}{ll}\text { Internal process prospective } \\
1 . & \text { Prevention cost } \\
2 . & \text { Appraisal cost } \\
3 . & \text { Percentage of defective output } \\
4 . & \text { External failure cost } \\
5 . & \text { Productivity } \\
6 . & \text { Average time to process order } \\
7 . & \text { Inventory management } \\
8 . & \text { Capacity utilization } \\
9 . & \text { Product variety } \\
\end{array}$ & & & \\
\hline $\begin{array}{ll}\text { Customer Prospective } \\
1 . & \text { Market share } \\
2 . & \text { Customer satisfaction } \\
3 . & \text { Loyalty of customer } \\
4 . & \text { Brand awareness } \\
5 . & \text { Number of complaints }\end{array}$ & & & \\
\hline $\begin{array}{ll}\text { Employee } & \text { Prospective } \\
\text { 1. } & \text { Percentage of staff turnover } \\
\text { 2. } & \text { Number of training programs } \\
\text { 3. } & \text { Employee satisfaction } \\
\text { 4. } & \text { Performance appraisal ratings } \\
5 . & \text { Increase in service knowledge }\end{array}$ & & & \\
\hline $\begin{array}{ll}\text { Financial Prospective } \\
1 . & \text { Net profit change } \\
2 . & \text { Revenue per cover } \\
3 . & \text { Food and Beverage cost } \\
4 . & \text { Overall revenue of the outlet } \\
5 . & \text { Return on investments }\end{array}$ & & & \\
\hline
\end{tabular}

Application of Balances Scorecard in Hospitality Industry

Balanced Scorecard allows hotel managers to assess an integrated approach to achieving strategic goals. The panels perform economic and non-financial measures that measure performance, focusing on different aspects of the business. In the hotel industry, the main categories of signalling allow the administrator to see visible comments that can be used to optimize your organization.

\section{Financial}

Revenues and revenues for the available space are usually balanced scorecard's common economic indicators. Note these data points and the total amount of revenue from the properties and site efficiency. If your earnings have decreased the available site, you should adjust them. Other financial measures such as earnings per share, net profit and share prices are also included in the economic category.

\section{Customer}

Maintenance costs, accidents and quality measures are part of the category of internal balanced scorecard business processes. These have a direct impact on net profit and earnings per share. In the hotel industry, competition should be conducted by the most efficient way possible service providers to maintain their market share and win customers. Although the rooms are confused and require a lot of maintenance, management needs to know new capital costs. Effective internal processes are crucial to the competitiveness of the hotel.

\section{Internal Business Process}

Hours training, staffing and staff turnover are among the appropriate learning and development parameters for hotel operators. In particular, staff turnover is an important sign of how the organization develops its employees. If your team is not satisfied, it may lead to a poor user experience. Employees are entitled to differentiate the hotel from their competitors and help your organization realize the real potential of their revenue.

\section{Learning and Growth}

Hours of training, skill levels attained and personnel turnover are among the learning and growth metrics relevant to hotel operators. In particular, personnel turnover is an important sign of how an organization is developing its employees. If personnel are unhappy, it can lead to poor customer experiences. Employees have the power to set a hotel apart from competitors and help their organization realize its true revenue potential.

\section{Advantages of performance measures:}

The balanced scorecard has various measures under each of its perspectives which are presumed to be deriving outcome measures of an organisation [25]. The owners and managers goal can be aligned to overcome the problems in operations using the balanced scorecard [26]. The usage of adapted performance measures for measuring the performance of a new service development will benefit in clarifying the strategy, linking to the financial goals, helps to communicate throughout the organization, aligning individual and unit goal to match the objectives and conduction periodic review on performance. 


\section{Limitations of Performance measurement:}

With the competitive environment changing regularly, it is difficult to have a simple vision for the organisation. The more complex the strategy is, the more complex the balanced scorecard will be. Wangodo et al, 2010 explained that these performance measures can be reliable only based on the accuracy of the information collected. Moreover, performance measures are time consuming and require time and energy to be invested into it[23].

\section{CONCLUSION}

The review has identified the various factors that motivate an organisation to develop a new product or to innovate, the success factors of the new product developed and the process of innovation. Also, the performance measurement methods have been identified and had been linked with the innovation in an organisation to derive with various performance measures for a hospitality organisation. Moreover, the importance of measuring various aspects of performance had been identified and the fact that to sustain the success, proper analysis at regular intervals were mandatory.

Author Profile :

Author 1.

\section{REFERENCES}

1. Peters, $\mathbf{M}$ and Pikkemaat, B, Innovation in Hospitality and tourism, vol.6, The Haworth Hospitality press, Binghamton 2005.

2. Rogers, E.M.Diffusion of Innovations, The Free press, New York, 3rd edition 1983.

3. Drucker, P.F., 1985, Innovation and Entrepreneurship: Practices and Principles, The free press, New York

4. Zahra, S.A. and Covin, J.G. (1994) The Financial Implications of Fit between Competitive Strategy and Innovation Types and Sources. The Journal of High Technology Management Research, 5, 183211.http://dx.doi.org/10.1016/1047-8310(94)90002-7

5. Jean Gadrey, FaïzGallouj, Olivier Weinstein. New modes of innovation: how services benefit industry. International Journal of Service Industry Management, Emerald, $1995, \quad 6 \quad$ (3), $\quad$ pp.4 $\quad$ - 16 Ff10.1108/09564239510091321ff. ffhalshs-01114102f

6. Bessant, J., Lamming, R., Noke, H. and Philip, W. Managing innovation beyond the steady state, Technovation, Vol.25 No.12 (2005)

7. Oke, A. (2007), "Innovation types and innovation management practices in service companies", International Journal of Operations \& Production Management, Vol. 27 No. 6, pp. 564-587. https://doi.org/10.1108/01443570710750268

8. MikaelaBackman, Johan Klaesson, OzgeOner. Innovation in the hospitality industry: Firm or location. Tourism Economic Sage Journals. Volume: 23 issue: 8, page(s): 1591-1614. 2017.

9. DivyaSathyanarayanan. International hotel chains like Marriott, Starwood looking to scale up properties in India. 2019 October 20 [Internet] Updated on 2016 April 26. Economictimes.indiatimes.com

10. Olivier Harnisch. Reviving the Spirit of Innovation in the Hospitality Industry. 2019 January 12 [Internet] Updated 2018 July 18 Available from: https://www.hospitalitynet.org/opinion/4089279.html

11. Rowley, J., 2011, Towards an Innovation-type mapping tool, Management decisions, Vol.49, No.1 [online]
12. Evan, W.M., 1966, Organisational lag, Human Organisations, Vol.25 No.1

13. Dewar, R.D. and Dutton, J.E., 1986, The Adaption of Radical and Incremental Innovations: an empirical analysis, Management Service, Vol.32, No.11

14. Knight, K.E., 1967, A Descriptive model of Intra-firm innovation process, Journal of management, Vol.40, No.4

15. Francis, D. and Bessant, J., 2007, targeting Innovation and implications for capability development, Technovation, Vol.25, No.3

16. Ottenbacher, M. C., 2007. Innovation management in hospitality industry: Different strategies for achieving success, Journal of Tourism and Hospitality Research 31 (4): 431-57 [online] Available at: http://jht.sagepub.com/content/31/4/431

17. Fernandez, M.C.L., Bedia, A.M.S. and Lopez, R.G., 2011, Factors Encouraging Innovation in Spanish Hospitality Firms, Cornell Hospitality Quarterly, [online]Available http://cqx.sagepub.com/content/52/2/144

18. Karniouchina, E., Victorino, L., \&Verma, R., 2006, Product and service innovation: Ideas for future crossdisciplinary research, Journal of Product Innovation Management, Vol.23, No.3

19. Tate, Sengupta, A. and Dev, C.S, 2010, Service Innovation: Applying the 7-I model to improve brand positioning at the Taj Holiday village Goa, India, Journal of tourism and Hospitality research [online] available at:http://cqx.sagepub.com/content/52/1/11.abstract

20. SubnuPerera. Innovation and its Contribution for a Hotel Product andits Online Presence. Universal Journal of Management 2(7): 241-264, 2014 http://www.hrpub.orgDOI: 10.13189/ujm.2014.02070

21. Fredrick NyongesaOduori. New service development strategy and process:Considering concepts from the financial sector in ananalysis of the hospitality sector in Kenya.

22. Elena A. Dzhandzhugazovaa, et.al.,Innovations in Hospitality Industry. International Journal of Environmental \& Science Education 2016, Vol. 11, No. 17, 10387-10400.

23. Jago, L. and Seers, S.B., 2006, Performance measurement in Small motels in Australia, Tourism and Hospitality Research, Vol.2, No.2

24. Wadango, B.I., Edwin, O. and Oscar, K.O., 2010, managerial Roles and Choice of Performance measures in the Kenyan five-star hotels using a cross-sectional co relational design, Managing Leisure, Vol.13, No.6

25. Kaplan, S. and Norton, P., 2004, the Balanced scorecard - Measures that drive performance, Harvard business review [online] available at: http://www.stevenstech.edu/MSISCourses/450/Articles/ValueOfIT/TheBala ncedScoreCard.pdf

26. Huang, H.C, Chu, W. and Wang, W.K., 2007, Strategic Performance measurement and Value Drivers: Evidence from International Tourist Hotels in an Emerging Economy, The Service Industries Journal, Vol.27, No.8

27. Johne, A. and Storey, C., 1997, New Service D2evelopment: a review of the literature and annotated bibliography, Management working paper B97/2, City University Business School, London

28. Howard M. Armitage\&CameronScholey. Using StrategyMaps to DrivePerformance. The Society of Management Accountants of Canada. ISBN 1-55302193-2 2006 Available from: http://www.cimaglobal.com/documents/importeddocume nts/tech_mag_strategy_ mapping_march07.pdf 
29. Gadrey, J., Gallouj, F. And Weinstein, O., 1995, New Modes of Innovation: how services benefit industry, International Journal of service Industry Management, Vol. 6 No. 3.

\section{AUTHORS PROFILE}

First Author: A. Arun ,Hotel Management Faculty with Master of Philosophy (M.Phil) in Hotel and Catering Management from Vels University, Chennai. Working as an Assistant Professor in Vels Institute of Science Technology and Advanced Studies, published about 25 articles in national and international journals listed in UGC or Scopus Indexed journals including a chapter in an International book. Attended and presented many papers nationally and internationally and also been awarded the best presenter award in an International Conference at Malaysia on September 2019. Awarded the "Best Young Faculty Award" under GRABS AWARDS 2019 from GRAB Educational Trust Chennai on February 2019 and the "Insc Research Excellence Award 2019" under InSc AWARDS from the Institute of Scholars Bangalore, Karnataka

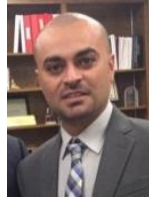

Second Author: Ali A. Alalmai. Assistant professor at Jazan University, Vice Dean for academic affairs at Community college.Phd in Hospitality Administration from Texas Tech University, M.B.A in Hospatitlty with

University. concentration in marketing from Hohnson and Wales 